ALCHEMY Jurnal Penelitian Kimia

Laman resmi: https://jurnal.uns.ac.id/alchemy

\title{
Validasi Metode Penentuan Benzena, Toluena dan Xilena pada Sampel Udara dan Tanah Menggunakan Kromatografi Gas
}

\author{
Aman Sentosa Panggabean*, Tika Widyastuti, Noor Hindryawati \\ Program Studi Kimia, FMIPA, Universitas Mulawarman Jl. Barong Tongkok Kampus Gn. Kelua, \\ Samarinda, 75119 \\ * Corresponding author \\ E-mail: amanspanggabean@yahoo.com
}

DOI: 10.20961/alchemy.15.1.25522.177-189

Received 24 November 2018, Accepted 21 February 2019, Published 01 March 2019

\begin{abstract}
ABSTRAK
Penelitian tentang validasi metode penentuan kadar benzena, toluena dan xilena pada sampel udara dan tanah dengan menggunakan kromatografi gas telah dilakukan. Untuk mendapatkan hasil pengukuran yang valid, beberapa parameter penting yang berpengaruh dalam validasi metode telah ditentukan. Beberapa parameter penting yang dilakukan adalah penentuan besaran dasar kromatografi yang meliputi: waktu retensi, kapasitas (k'), faktor selektivitas ( $\alpha$ ) dan kinerja analitik yang meliputi: penentuan linearitas (r), limit deteksi (LOD), limit kuantitasi (LOQ), presisi dan akurasi. Hasil penelitian penentuan kinerja analitik sangat baik ditunjukkan oleh nilai presisi sebagai $\% \mathrm{KV}<2 / 3$ nilai KV Horwitz, LOD untuk masing-masing senyawa benzena, toluena dan xilena adalah $0,02 \mathrm{mg} / \mathrm{L} ; 0,59 \mathrm{mg} / \mathrm{L}$ dan $0,08 \mathrm{mg} / \mathrm{L}$ serta LOQ untuk masing-masing senyawa benzena, toluena dan xilena adalah $0,07 \mathrm{mg} / \mathrm{L} ; 1,99 \mathrm{mg} / \mathrm{L}$ dan $0,27 \mathrm{mg} / \mathrm{L}$. Akurasi metode ini sangat baik ditunjukkan dengan nilai presentase perolehan kembali masing-masing senyawa benzena, toluena dan xilena untuk sampel tanah sebesar $102,61 \pm 4,61 \% ; 101,65 \pm 7,41 \% ; 102,15 \pm 4,15 \%$, dan untuk sampel udara masing-masing senyawa sebesar $101,69 \pm 5,77 \% ; 102,08 \pm 5,43 \%$ dan $98,55 \pm 5,11 \%$. Berdasarkan hasil penelitian ini, metode kromatografi gas dapat digunakan dalam penentuan benzena, toluena dan xilena pada sampel udara dan tanah dengan memberikan hasil yang valid.
\end{abstract}

Kata kunci: benzena, kromatografi gas, toluena, validasi, xilena.

\begin{abstract}
Validation Method on The Determination of Benzene, Toluene and Xylene in Air and Soil Samples Using Gas Chromatography. The present study investigated the method for the determination of the content of benzene, toluene, and xylene in air and soil samples using gas chromatography. To obtain a valid measurement result, several important parameters that influence the method validation have been determined. The several important parameters carried out are the determination of the basic chromatographic such as retention time, capacity factor $\left(\mathrm{k}^{\prime}\right)$, selectivity $(\alpha)$ and analytical performance measurement includes: the determination of linearity (r), limit of detection (LOD), limit of quantitation (LOQ), precision and accuracy. The result of analytical performance of the research are well verified, in which the value of precision was \% CV $<2 / 3 \mathrm{CV}$ Horwitz value, LOD for benzene, toluene, and xylene compound were 0.02 $\mathrm{mg} / \mathrm{L}, 0.59 \mathrm{mg} / \mathrm{L}, 0.08 \mathrm{mg} / \mathrm{L}$, respectively, and LOQ for benzene, toluene and xylene compounds was 0.07 $\mathrm{mg} / \mathrm{L}, 1.99 \mathrm{mg} / \mathrm{L}$ and $0.27 \mathrm{mg} / \mathrm{L}$ respectively. This method achieved high accuration, indicated by a percentage of recovery value of benzene, toluene, and xylene for soil samples of $102.61 \pm 4.61 \%$; $101.65 \pm$ $7.41 \% ; 102.15 \pm 4.15 \%$, and for air samples was $101.69 \pm 5.77 \%, 102.08 \pm 5.43 \%$, and $98.55 \pm 5.11 \%$ respectively. Based on the results of this research, the method presented in this study can be applied for the
\end{abstract}


determination of benzene, toluene, and xylene using gas chromatography in air and soil samples with valid results.

Keywords: benzene, gas chromatography, toluene, validation, xylene.

\section{PENDAHULUAN}

Perkembangan industri pada beberapa dekade terakhir ini berkembang dengan pesat, karena sangat berpengaruh dengan tingkat kebutuhan dan kehidupan manusia. Salah satu industri tersebut adalah industri petrokimia. Beberapa bahan yang dihasilkan dari industri petrokimia ialah karet, nilon, lem, pipa, plastik, obat-obatan, LPG, rafinat dan masih banyak benda lainnya. Macam-macam benda tersebut ialah produk yang dihasilkan dari minyak bumi ataupun gas alam. Dari proses industri petrokimia ini dihasilkan senyawa kimia yang sering terdeteksi seperti $\mathrm{H}_{2} \mathrm{~S}, \mathrm{NH}_{3}$, metil etil keton (MEK), klorin, merkuri, dan benzena toluena xilena (BTX) (Indrawan and Oginawati, 2014). Senyawa BTX telah menjadi fokus dari beberapa studi tentang biomeridasi dan biodegradasi (Krumholz et al., 1999). Safitri et al. (2013) telah menggunakan teknologi ultrafiltrasi untuk pengolahan alir limbah eksploitasi minyak bumi (produced water).

Senyawa BTX ini banyak digunakan sebagai pelarut dalam suatu proses industri dan memiliki sifat yang mudah menguap. Senyawa benzena merupakan bahan kimia yang bersifat toksik dan karsinogenik terhadap kesehatan (White et al., 2014) serta dapat menyebabkan leukemia sampai kanker pada sistem hematologi manusia (Smith, 2010). Toluena dan xilena bukan merupakan senyawa karsinogenik namun harus ada pada level rendah pada lingkungan karena sifat toksiknya. Gejala-gejala yang umum terjadi apabila seseorang terkontaminasi senyawa BTX adalah terganggunya sistem syaraf pusat, antara lain mual, muntah, pusing dan sakit kepala. Apabila terkontaminasi dengan konsentrasi yang cukup tinggi akan mengakibatkan gejala seperti gemetar, lemas, gangguan pada tekanan darah, sakit kepala, pusing tiba-tiba, vertigo, muntah, dehidrasi hingga kematian (Wispriyono and Handoyo, 2016).

Senyawa BTX merupakan senyawa yang biasa terdapat pada tanah dan air tanah yang tercemar oleh bensin atau produk minyak bumi lainnya (Moskovkina and Milina, 2008). Lingkungan stasiun pengisian bahan bakar umum (SPBU) merupakan lingkungan yang berpotensi tercemar oleh bensin ataupun produk minyak bumi yang lain. Secara tidak langsung adanya tumpahan-tumpahan bensin atau produk minyak bumi lainnya akan ada yang mengalami biodegradasi oleh mikroba-mikroba dan ada pula yang menguap. Sebagian dari polutan hidrokarbon yang masuk ke dalam tanah akan mencemari tanah 
tersebut. Produk-produk minyak bumi ini mengandung senyawa-senyawa hidrokarbon diantaranya ialah BTX (Safitri et al., 2013), sehingga harus dilakukan analisis khusus untuk mengetahui keberadaan senyawa hidrokarbon tersebut.

Teknik analisis yang umum dilakukan untuk menentukan senyawa BTX adalah kromatografi terutama kromatografi gas dengan flame ionization detector (FID) (Yamada et al., 2004) dan detektor mass spectroscopy (MS) (Bahrami et al., 2011). Senyawa BTX dilaporkan dapat dianalisis dengan HPLC menggunakan detektor fluoresensi, fasa diamnya adalah $\beta$-siklodekstrin dan sampel dipreparasi dengan cara ekstraksi cair menggunakan pelarut metilen klorida dan etil asetat (Campos-Candel et al., 2009). Kromatografi gas memiliki kelebihan penting dibandingkan metode yang lainnya. Kromatografi gas mampu dengan cepat menganalisis senyawa BTX dalam matriks sampel yang kompleks dan dapat melakukan analisis kualitatif dan kuantitatif yang tepat dari berbagai komponen secara cepat (González and Herrador, 2007).

Metode analisis dapat digunakan sebagai analisis rutin, dengan hasil yang dapat dipertanggungjawabkan dengan baik, tingkat ketelitian dan ketepatan yang tinggi serta perlu dilakukan suatu tahapan validasi metode (Panggabean et al., 2018; Taufiq et al., 2016). Validasi metode dilakukan sebagai suatu proses penilaian pada metode analisis tertentu berdasarkan percobaan laboratorium guna membuktikan bahwa metode tersebut telah memenuhi persyaratan untuk diaplikasikan (Harmita, 2004). Kinerja kromatografi gas dalam analisis senyawa BTX pada sampel tanah dan udara belum ditentukan pada Laboratorium Balai Keselamatan dan Kesehatan Kerja Samarinda. Pendekatan yang dilakukan adalah melakukan penentuan linearitas, batas deteksi dan batas kuantifikasi, uji presisi dan akurasi metode. Jika parameter-parameter tersebut telah memenuhi syarat validasi maka metode yang digunakan dapat dipertanggung jawabkan sehingga dapat digunakan sebagai analisis rutin dalam penentuan senyawa BTX dalam berbagai sampel.

\section{METODE PENELITIAN}

Alat-alat yang digunakan dalam penelitian ini adalah Kromatografi Gas-FID (GC2010 Shimadzu) dengan kolom kapiler fused silica (30 m x 0,32 mm ID; $1 \mu \mathrm{m}$ film 100\% PEG or equivalent), seperangkat unit komputer, neraca analitik, pipet gondok, karet penghisap, labu ukur, pipet volume, syringe, botol vial, charcoal tube dan corong pisah. 
Bahan-bahan yang digunakan dalam penelitian ini adalah karbon disulfida $\left(\mathrm{CS}_{2}\right)$, gas pembawa helium, larutan standar benzena, toluena dan xilena (E’Merck) dengan kualitas pro analysis (p.a.), sampel udara dan tanah.

\section{Pengkondisian Alat}

Optimasi terhadap kondisi alat kromatografi gas yang digunakan saat pengukuran, dilakukan dengan mengatur suhu awal kolom $50{ }^{\circ} \mathrm{C}$ dilanjutkan kenaikkan suhu secara gradien $10{ }^{\circ} \mathrm{C} /$ menit selama 10 menit. Suhu injektor diatur sebesar $225^{\circ} \mathrm{C}$, suhu detektor sebesar $225^{\circ} \mathrm{C}$ dan kecepatan aliran gas pembawa sebesar $16,7 \mathrm{~mL} / \mathrm{menit}$.

\section{Pembuatan Larutan Standar Benzena, Toluena dan Xilena}

Pembuatan larutan standar BTX 1000 mg/L dilakukan dengan cara memasukkan masing-masing larutan benzena, toluena dan xilena ke dalam labu ukur $50 \mathrm{~mL}$ hingga diperoleh berat larutannya $\pm 0,05 \mathrm{~g}$, selanjutnya diencerkan dengan larutan $\mathrm{CS}_{2}$ (karbon disulfida) kemudian dihomogenkan. Larutan induk BTX 1000 mg/L tersebut diencerkan menjadi $10 \mathrm{mg} / \mathrm{L}$ dengan cara dipipet $0,5 \mathrm{~mL}$ larutan induk dimasukkan ke dalam labu ukur $50 \mathrm{~mL}$, lalu ditambahkan dengan larutan $\mathrm{CS}_{2}$ kemudian dihomogenkan (Yamada et al., 2004). Untuk pekerjaan selanjutnya, masing-masing konsentrasi larutan seri standar benzena $(0,5 ; 1,0 ; 1,5 ; 2,0$ dan $3,0 \mathrm{mg} / \mathrm{L})$, toluena $(1,0 ; 1,5 ; 2,0 ; 2,5$ dan $3,0 \mathrm{mg} / \mathrm{L})$ dan xilena $(2,0 ; 3,0 ; 4,0 ; 5,0$ dan 6,0 mg/L) diencerkan dari larutan standar $10 \mathrm{mg} / \mathrm{L}$.

\section{Persiapan Blanko}

Larutan karbon disulfida $\left(\mathrm{CS}_{2}\right)$ sebanyak $1 \mathrm{~mL}$ dimasukkan ke dalam botol vial kemudian didiamkan selama 30 menit. Setelah itu diambil $1 \mu \mathrm{L}$ menggunakan syringe dan diinjeksikan ke dalam kromatografi gas.

\section{Pengambilan Sampel Udara}

Sampel udara diambil pada lokasi lingkungan stasiun pengisian bahan bakar umum (SPBU) Jl. Kusuma bangsa dengan titik koordinat S: $0^{\circ} 29^{\prime} 24^{\prime \prime}$ dan E: $117^{\circ} 08^{\prime} 47^{\prime \prime}$. Pengambilan sampel dilakukan sebanyak 7 kali dengan hari yang berbeda, dilakukan dengan mempersiapkan dan merakit peralatan personal sampling pump (pompa pengisap udara), selang dan bahan silicon, flowmeter dan charcoal tube. Personal sampling pump diaktifkan dan diatur laju aliran udara sehingga menunjukkan angka laju aliran udara 0,2 L/menit dengan menggunakan flowmeter. Setelah itu personal sampling pump dimatikan dan flowmeter dilepaskan. Charcoal tube diganti dengan yang baru kemudian dipotong kedua ujung charcoal tube dengan pemotong kaca setelah itu dilakukan sampling selama 
60 menit. Setelah selesai charcoal tube ditutup dengan penutupnya dan dibawa sampel ke laboratorium untuk dianalisis.

\section{Pengambilan Sampel Tanah}

Sampel tanah diambil dari lokasi yang sama dengan sampel udara. Sampel diambil secara acak, kemudian tanah dimasukkan ke dalam botol vial dan ditutup rapat. Setelah itu sampel dibawa ke laboratorium untuk dianalisis.

\section{Uji Kualitatif Senyawa BTX dengan Kromatografi Gas}

Uji kualitatif dilakukan dengan membuat masing-masing larutan benzena, toluena dan xilena dengan konsentrasi tertentu dan membuat larutan campuran benzena, toluena dan xilena kemudian diinjeksikan masing-masing larutan sebanyak $1 \mu \mathrm{L}$ dan dilakukan 5 kali pengulangan. Setelah itu ditentukan waktu retensi yang diperoleh pada kromatogram dan dihitung nilai faktor kapasitas (k') dan selektifitasnya $(\alpha)$ dengan rumus:

$$
\begin{aligned}
& \text { Faktor Kapasitas }\left(\mathrm{k}^{\prime}\right)=\frac{t_{R}-t_{0}}{t_{0}} \\
& \text { Selektivitas }(\alpha) \quad=\frac{k_{2}^{\prime}}{k_{1}^{\prime}}
\end{aligned}
$$

\section{Uji Linearitas}

Pengujian linearitas untuk penentuan senyawa BTX pada sampel udara dan tanah dilakukan dengan mengukur luas area larutan seri standar BTX campuran pada berbagai variasi konsentrasi. Berdasarkan data yang didapatkan lalu dibuat kurva larutan seri standar -vs- luas area hasil pengukuran dan dihitung nilai koefisien korelasi (r).

\section{Uji LOD (Limit of Detection)}

Uji LOD, yang ditentukan adalah LOD instrument. Penentuan LOD dilakukan secara statistik melalui garis regresi linier dari kurva kalibrasi. Hasil respon instrumen y berhubungan linier dengan konsentrasi x. Besar limit deteksi pada umumnya dinyatakan dalam 3Sa/b. Notasi b ialah slope dan SD ialah standar deviasi.

$$
\mathrm{LOD}=3 \times \mathrm{SD} / \mathrm{b}
$$

\section{Uji LOQ (Limit of Quantity)}

Uji LOQ yang ditentukan adalah LOQ instrument. Penentuan LOQ dilakukan secara statistik melalui garis regresi linier dari kurva kalibrasi. Dalam hal ini, respon instrumen y berhubungan linier dengan konsentrasi x. Besar limit deteksi pada umumnya dinyatakan dalam 10Sa/b. Notasi b ialah slope dan SD ialah standar deviasi.

$$
\mathrm{LOQ}=10 \times \mathrm{SD} / \mathrm{b}
$$




\section{Uji Presisi}

Uji presisi ini dilakukan dengan cara menentukan luas area kromatogram senyawa BTX dari sampel tanah dan udara. Penetapan kadar BTX pada sampel udara dilakukan sebanyak 7 kali perulangan. Dari hasil pengukuran yang diperoleh dihitung rata-rata konsentrasi BTX dalam sampel. Standar deviasi, \% KV dan KV Horwitz, dihitung dengan rumus:

$$
\begin{aligned}
& \% \mathrm{KV}=\frac{\mathrm{SD}}{\overline{\mathrm{x}}} \times 100 \% \\
& \% \mathrm{KV} \text { Horwitz }=\left(2^{1-0,5 \times\left(\log \left(\mathrm{C} \times 10^{-6}\right)\right)}\right)
\end{aligned}
$$

\section{Uji Akurasi}

Uji akurasi dilakukan dengan metode adisi standar. Sampel tanah dan charcoal tube hasil sampling udara ditimbang $\pm 0,2 \mathrm{~g}$ kemudian ditambah $1 \mathrm{~mL}$ larutan standar benzene dengan konsentrasi 0,$4599 ; 0,9198 ; 1,3797 ; 1,8396 ; 2,2995 ; 2,7594$ dan 3,2193 mg/L, toluene dengan konsentrasi 0,$5067 ; 1,0134 ; 1,5201 ; 2,0268 ; 2,5335 ; 3,0402$; dan 3,5469 $\mathrm{mg} / \mathrm{L}$, dan xilena dengan konsentrasi 1,0764; 2,1528; 3,2292; 4,3056; 5,3820; 6,4548; dan

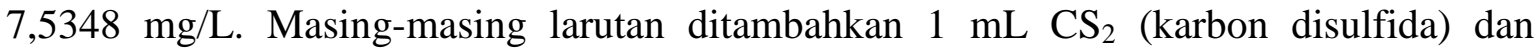
dihomogenkan dengan menggunakan shaker, setelah itu diinjeksikan ke dalam kromatografi gas sebanyak $1 \mu \mathrm{L}$. Pengukuran dilakukan sebanyak 7 kali. Nilai uji akurasi didapatkan dari nilai \% recovery yang diperoleh dengan menghitung konsentrasi BTX adisi yang terdeteksi dari hasil kromatogram dan dibandingkan dengan konsentrasi BTX adisi yang sebenarnya.

\section{HASIL DAN PEMBAHASAN}

\section{Analisis Kualitatif Senyawa BTX dengan Kromatografi Gas}

Analisis kualitatif senyawa BTX secara kromatografi gas dilakukan untuk menentukan kualitas pemisahan senyawa BTX dalam kolom fasa diam dengan menentukan besaran dasar kromatografi seperti waktu retensi $\left(\mathrm{t}_{\mathrm{r}}\right)$, faktor kapasitas $\left(\mathrm{k}^{\prime}\right)$ dan selektifitas $(\alpha)$. Profil kromatogram pemisahan senyawa BTX dapat dilihat pada Gambar 1. 


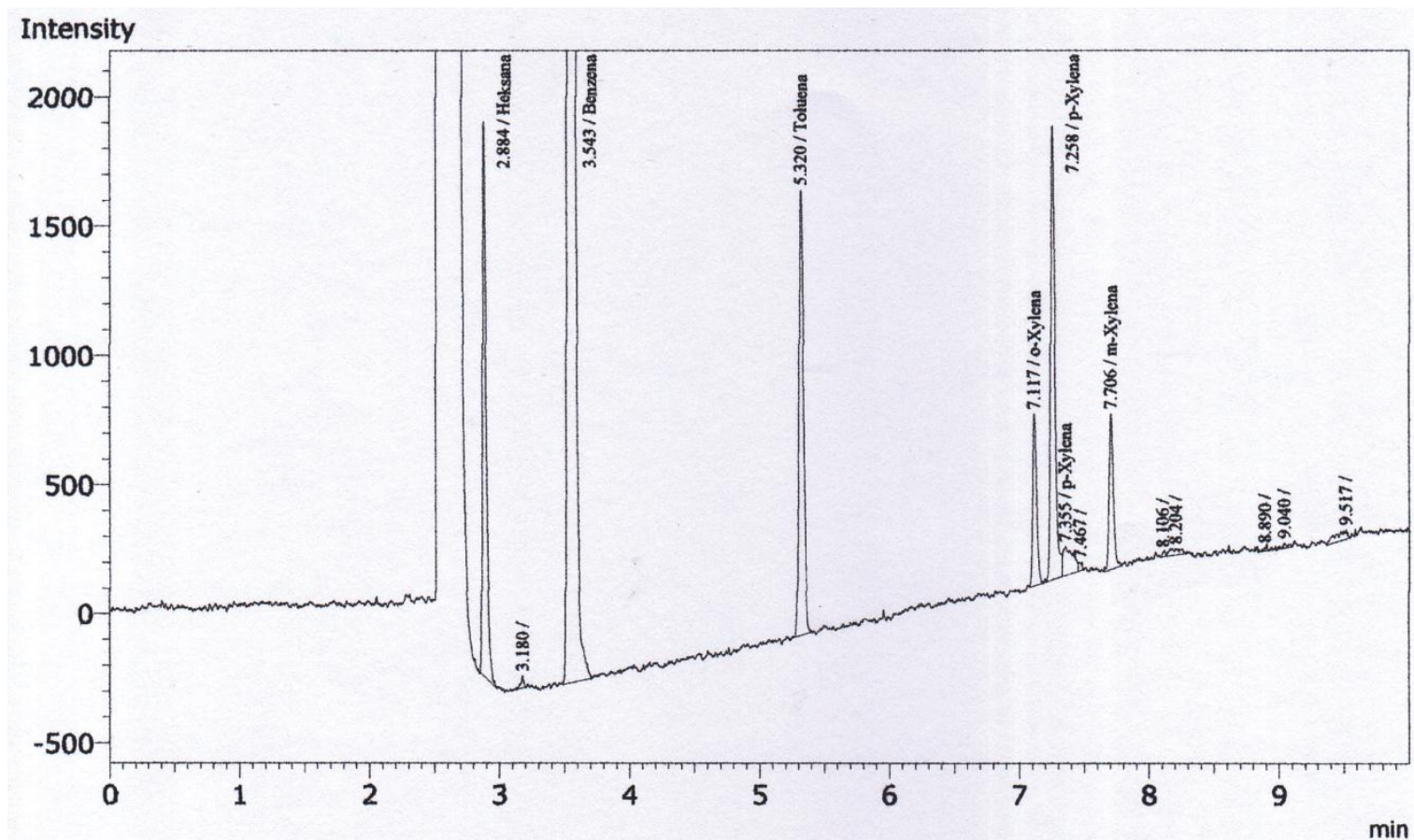

Gambar 1. Profil kromatogram pemisahan senyawa BTX dengan metode kromatografi gas (GC).

Berdasarkan hasil pengukuran diperoleh waktu retensi mati $\left(\mathrm{t}_{\mathrm{o}}\right)$ sebesar 2,844 menit. Selanjutnya ditentukan nilai faktor kapasitas (k') dan selektifitas $(\alpha)$ senyawa BTX, seperti dapat dilihat pada Tabel 1.

Tabel 1. Pengukuran parameter besaran dasar kromatografi pemisahan senyawa benzena, toluena dan xilena menggunakan kromatografi gas.

\begin{tabular}{|c|c|c|c|c|c|}
\hline \multirow{3}{*}{$\begin{array}{c}\text { Nama } \\
\text { senyawa }\end{array}$} & \multicolumn{4}{|c|}{ Parameter } & \\
\hline & \multirow{2}{*}{$\begin{array}{l}\text { Waktu retensi }\left(t_{\mathrm{r}}\right) \\
\text { menit }\end{array}$} & \multirow{2}{*}{$\begin{array}{l}\text { Kapasitas } \\
\qquad\left(\mathrm{k}^{\prime}\right)\end{array}$} & \multicolumn{3}{|c|}{ Faktor selektivitas $(\alpha)$} \\
\hline & & & $\begin{array}{c}\text { Benzena- } \\
\text { Toluena }\end{array}$ & $\begin{array}{l}\text { Toluena- } \\
\text { Xilena }\end{array}$ & $\begin{array}{c}\text { Benzena- } \\
\text { Xilena }\end{array}$ \\
\hline Benzena & $3,538 \pm 0,012$ & 0,23 & \multirow{3}{*}{3,76} & \multirow{3}{*}{1,77} & \multirow{3}{*}{6,65} \\
\hline Toluena & $5,317 \pm 0,062$ & 0,86 & & & \\
\hline Xilena & $7,256 \pm 0,025$ & 1,52 & & & \\
\hline
\end{tabular}

Hasil pengujian menunjukkan puncak senyawa benzena berdekatan dengan puncak pelarut $\mathrm{CS}_{2}$ ditunjukkan dari nilai k' sebesar 0,23. Faktor kapasitas (k') merepresentasikan perbandingan distribusi jumlah analit pada fasa diam dan fasa gerak. Nilai k' yang baik antara 1-10 (Raeni et al., 2018). Hal ini dapat dilihat pada nilai k' senyawa toluene dan xilena berturut-turut sebesar 0,86 dan 1,52; menunjukkan senyawa tersebut sudah terpisah dengan baik. Hasil ini didukung besaran selektifitas dari pemisahan puncak kromatogram 
senyawa benzena-toluena sebesar 3,76; senyawa toluene-xilena sebesar 1,77 dan senyawa benzene-xilena 6,65; menunjukkan kualitas pemisahan senyawa BTX telah terpisah dengan baik. Selektifitas $(\alpha)$ merupakan kemampuan fasa diam untuk mengikat analit, nilai ini dipengaruhi oleh sifat fasa diam dan relatif konstan pada berbagai komposisi fasa gerak. Semakin besar nilai selektifitas berarti makin baik puncak-puncak kromatogram senyawa tersebut terpisah (Panggabean et al., 2009).

\section{Linearitas}

Kurva kalibrasi dibuat dengan cara memplotkan hasil pengukuran luas area dari larutan seri standar senyawa BTX dengan konsentrasi larutan yang dibuat bervariasi. Tujuannya adalah untuk memperoleh suatu persamaan garis linear (linearitas). Linearitas adalah kemampuan untuk menunjukkan bahwa nilai hasil uji langsung atau diolah secara matematika, sebanding dengan konsentrasi analit pada batas rentang konsentrasi tertentu (Panggabean et al., 2014). Uji linearitas dinyatakan sebagai koefisien korelasi (r). Hasil pengukuran dapat dilihat pada Gambar 2.
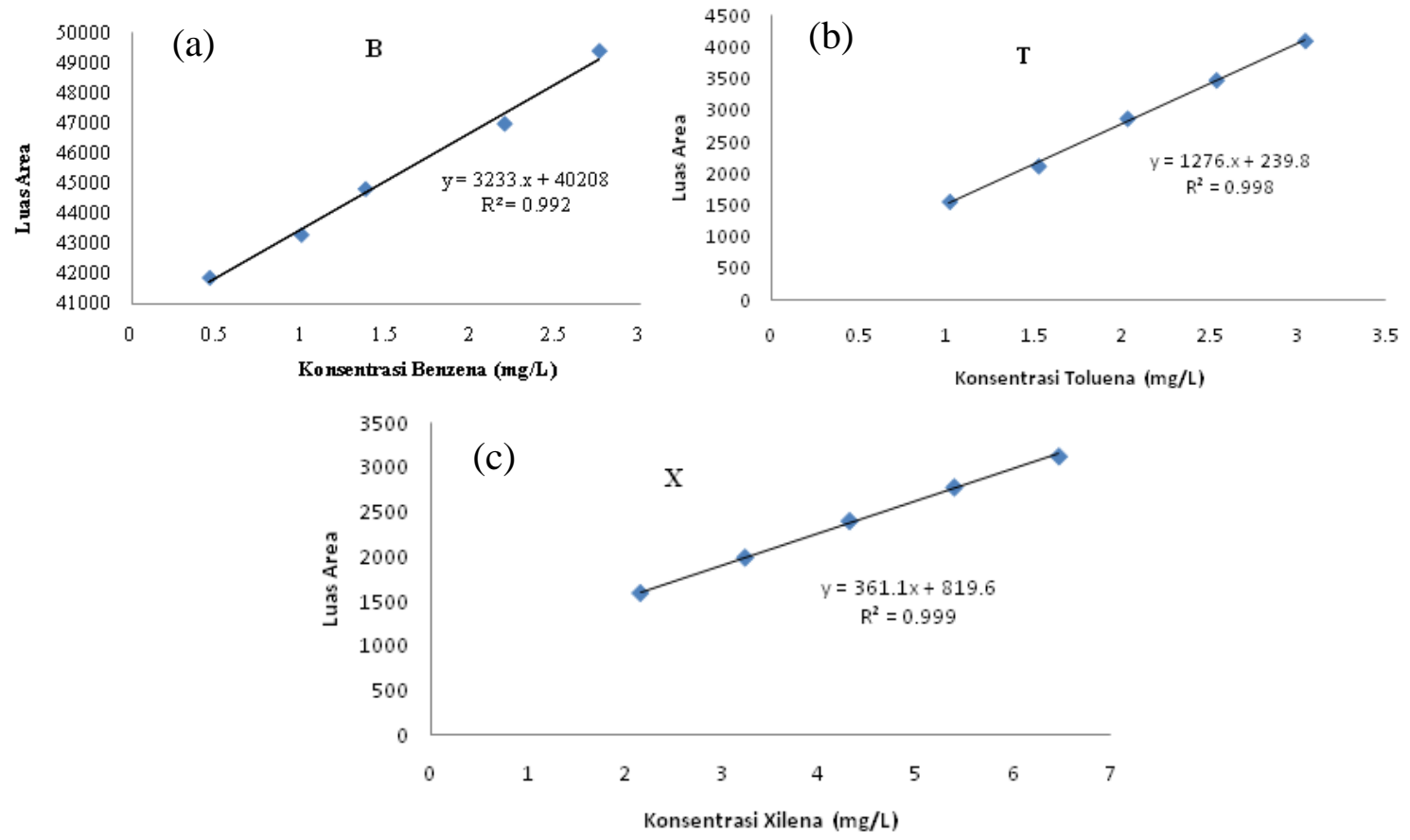

Gambar 2. Pembuatan kurva kalibrasi: (a) senyawa B (benzena), (b) senyawa $\mathrm{T}$ (toluena) dan (c) senyawa X (xilena) dengan metode kromatografi gas.

Berdasarkan Gambar 2. dapat diketahui persamaan garis liniear masing-masing senyawa benzene, toluena dan xilena seperti pada Tabel 2. Persyaratan yang memenuhi kriteria untuk koefisien korelasi ialah sebesar $r \geq 0,990$ (Riyanto, 2014). Nilai $r$ yang didapatkan menyatakan bahwa hasil data linieritas dinyatakan valid dan terdapat korelasi yang sangat kuat antara konsentrasi dan luas area. 
Tabel 2. Persamaan garis linear pada pembuatan kurva kalibrasi senyawa BTX

\begin{tabular}{cccc}
\hline Nama Senyawa & Persamaan garis regressi & $\mathrm{r}$ & $\mathrm{R}^{2}$ \\
\hline Benzena & $\mathrm{y}=3233 \mathrm{x}+40208$ & 0,995 & 0,992 \\
Toluena & $\mathrm{y}=1276 \mathrm{x}+239,8$ & 0,998 & 0,999 \\
Xilena & $\mathrm{y}=361,1 \mathrm{x}+819,6$ & 0,999 & 0,999 \\
\hline
\end{tabular}

\section{LOD dan LOQ}

Limit deteksi menyatakan konsentrasi atau massa minimum terkecil yang masih dapat terdeteksi oleh suatu metode analisis dengan tingkat kepercayaan yang tinggi. Dengan mengetahui limit deteksi dapat diperkirakan jumlah konsentrasi sampel minimum yang dibutuhkan dalam suatu proses analisis (Miller and Miller, 2005). Dalam penelitian ini, uji limit deteksi (LOD) dan limit kuantisasi (LOQ) yang ditentukan adalah LOD instrumen. Penentuan LOD dan LOQ dilakukan secara statistik menggunakan kurva standar BTX yang telah diperoleh pada uji linearitas sebelumnya.

Penentuan LOD dan LOQ dapat ditentukan dengan kurva kalibrasi (Miller and Miller, 2005). Hasil pengukuran untuk LOD masing-masing senyawa benzena, toluena dan xilena dapat dilihat pada Tabel 3.

Tabel 3. Penentuan jumlah LOD dan LOQ senyawa BTX dengan kromatografi gas

\begin{tabular}{ccc}
\hline Nama Senyawa & LOD $(\mathrm{mg} / \mathrm{L})$ & LOQ $(\mathrm{mg} / \mathrm{L})$ \\
\hline Benzena & 0,02 & 0,07 \\
Toluena & 0,59 & 1,99 \\
Xilena & 0,08 & 0,27 \\
\hline
\end{tabular}

Nilai ini menunjukkan konsentrasi analit terendah dan kuantitas terkecil yang dapat ditetapkan oleh suatu metode dengan diaplikasikan secara lengkap pada metode yang digunakan dengan kondisi yang disepakati di laboratorium uji. Dapat disimpulkan bahwa nilai LOD dan LOQ dapat diterima dan dinyatakan valid.

\section{Uji Presisi}

Ketelitian (presisi) dari penentuan senyawa BTX dengan metode kromatografi gas, dinyatakan sebagai persentase koefisien variansi (\% KV). Hasil presisi dinyatakan baik apabila nilai \% KV $\leq 2 / 3 \mathrm{KV}$ Horwitz (Harmita, 2004). Dalam penelitian ini, untuk uji presisi digunakan sampel dari tanah dan udara yang diukur berulang kali $(n=7)$ dengan kondisi pengukuran yang sama. Hasil pengukuran presisi menunjukkan bahwa \% KV dan KV Horwitz untuk senyawa benzena, toluene dan xilena yang dapat dilihat pada Tabel 4. 
Tabel 4. Hasil pengukuran nilai \% KV dan KV Horwitz senyawa BTX

\begin{tabular}{ccccc}
\hline Nama Senyawa & \multicolumn{2}{c}{ Sampel Tanah } & \multicolumn{2}{c}{ Sampel Udara } \\
\cline { 2 - 5 } & $\%$ KV & KV Horwitz & \% KV & KV Horwitz \\
\hline Benzena & 4,23 & 15,68 & 11,69 & 32,43 \\
Toluena & 5,19 & 15,75 & 8,77 & 23,91 \\
Xilena & 4,18 & 15,76 & 3,88 & 14,93 \\
\hline
\end{tabular}

Berdasarkan perhitungan secara statistik, hasil yang diperoleh menunjukkan bahwa pada penentuan presisi dari masing-masing senyawa BTX pada penelitian ini memiliki hasil $\% \mathrm{KV} \leq 2 / 3 \mathrm{KV}$ Horwitz, sehingga dapat disimpulkan bahwa data yang diperoleh memiliki nilai presisi yang baik dan data dapat dinyatakan valid.

\section{Uji Akurasi}

Akurasi menyatakan derajat kedekatan hasil analisis dengan kadar analit yang sebenarnya. Akurasi dinyatakan sebagai persen perolehan kembali (recovery) analit yang ditambahkan (Riyanto, 2014). Pada uji akurasi ini dilakukan dengan pengukuran sampel tanah dan udara yang telah ditambahkan standar BTX masing-masing sebanyak $1 \mathrm{~mL}$ kemudian dilakukan sebanyak 7 kali pembacaan sampel menggunakan kromatografi gas. Hasil pengukuran dapat dilihat pada Tabel 5 dan 6.

Berdasarkan Tabel 5 diperoleh \% recovery masing-masing senyawa benzena, toluena dan xilena untuk sampel udara sebesar 101,69 $\pm 5,77 \% ; 102,08 \pm 5,43 \%$ dan 98,55 $\pm 5,11 \%$. Untuk sampel tanah (Tabel 6 ) diperoleh \% recovery masing-masing senyawa benzena, toluena dan xilena sebesar 102,61 $\pm 4,61 \%$; 101,65 $\pm 7,41 \%$ dan $102,15 \pm 4,15 \%$. Hasil akurasi dinyatakan baik apabila diperoleh nilai dengan rentang 95 - $105 \%$ (Miller and Miller, 2005). Maka pada penelitian ini hasil uji akurasi masih masuk dalam rentang yang ditetapkan, sehingga data dapat dinyatakan valid. 
Tabel 5. Penentuan Senyawa BTX dalam Sampel Udara

\begin{tabular}{|c|c|c|c|c|c|c|c|c|c|c|c|}
\hline \multicolumn{4}{|c|}{ Benzena } & \multicolumn{4}{|c|}{ Toluena } & \multicolumn{3}{|c|}{ Xilena } & \multirow[b]{2}{*}{$\% \operatorname{Rec}$} \\
\hline [terukur] & \multicolumn{2}{|c|}{ [adisi] [ditemukan] } & \multirow{2}{*}{$\begin{array}{c}\text { \% Rec } \\
109,81\end{array}$} & \multirow{2}{*}{$\begin{array}{c}\text { [terukur] } \\
0,851\end{array}$} & \multicolumn{2}{|c|}{ [adisi] [ditemukan] } & \multirow{2}{*}{$\begin{array}{l}\text { \% Rec } \\
107,36\end{array}$} & \multirow{2}{*}{$\begin{array}{c}\text { [terukur } \\
1,045\end{array}$} & \multicolumn{2}{|c|}{ [adisi] [ditemukan] } & \\
\hline 0,758 & 0,4599 & 1,263 & & & 0,5067 & 1,395 & & & 1,0764 & 2,132 & 100,98 \\
\hline 0,966 & 0,9198 & 1,901 & 101,65 & 1,100 & 1,0134 & 2,194 & 107,95 & 1,043 & 2,1528 & 2,989 & 90,39 \\
\hline 0,918 & 1,3797 & 2,327 & 102,12 & 0,872 & 1,5201 & 2,368 & 98,41 & 1,210 & 3,2292 & 4,273 & 94,85 \\
\hline 0,643 & 1,8396 & 2,445 & 97,96 & 0,866 & 2,0268 & 2,775 & 94,19 & 1,073 & 4,3056 & 5,521 & 103,30 \\
\hline 0,879 & 2,2995 & 2,986 & 91,63 & 0,734 & 2,5335 & 3,268 & 100,02 & 1,185 & 5,3820 & 6,757 & 103,53 \\
\hline 0,773 & 2,7594 & 3,610 & 102,81 & 0,882 & 3,0402 & 4,143 & 107,26 & 1,172 & 6,4584 & 7,308 & 95,01 \\
\hline 0,595 & 3,2193 & 4,003 & 105,86 & 0,937 & 3,5469 & 4,46 & 99,33 & 1,065 & 7,5348 & 8,734 & 101,78 \\
\hline & Averag & & 101,69 & & & & 102,08 & & & & 98,55 \\
\hline & STDE & & 5,77 & & & & 5,43 & & & & 5,11 \\
\hline
\end{tabular}

Tabel 6. Penentuan Senyawa BTX dalam Sampel Tanah

\begin{tabular}{|c|c|c|c|c|c|c|c|c|c|c|c|}
\hline \multicolumn{5}{|c|}{ Benzena } & \multicolumn{4}{|c|}{ Toluena } & \multicolumn{3}{|c|}{ Xilena } \\
\hline [terukur] & [adisi] & [ditemukan] & $\%$ Rec & [terukur] & [adisi] & [ditemukan] & $\%$ Rec & [terukur] & [adisi] & [ditemukan] & $\% \operatorname{Rec}$ \\
\hline 0.007 & 0.4599 & 0.489 & 104.81 & 0.065 & 0.5067 & 0.629 & 111.31 & 0.656 & 1.0764 & 1.811 & 107.30 \\
\hline 0.007 & 0.9198 & 1.003 & 108.28 & 0.067 & 1.0134 & 0.984 & 90.49 & 0.658 & 2.1528 & 2.940 & 106.00 \\
\hline 0.006 & 1.3797 & 1.361 & 98.21 & 0.067 & 1.5201 & 1.518 & 95.45 & 0.751 & 3.2292 & 4.089 & 103.37 \\
\hline 0.007 & 1.8396 & 1.910 & 103.45 & 0.075 & 2.0268 & 2.273 & 108.45 & 0.666 & 4.3056 & 5.152 & 104.19 \\
\hline 0.012 & 2.2995 & 2.472 & 106.98 & 0.100 & 2.5335 & 2.79 & 106.18 & 0.538 & 5.3820 & 5.920 & 100.00 \\
\hline 0.005 & 2.7594 & 2.788 & 100.86 & 0.062 & 3.0402 & 3.099 & 99.89 & 0.846 & 6.4584 & 7.147 & 97.56 \\
\hline 0.006 & 3.2193 & 3.086 & 95.67 & 0.065 & 3.5469 & 3.604 & 99.78 & 0.734 & 7.5348 & 8.012 & 96.59 \\
\hline \multicolumn{3}{|c|}{ Average } & 102,61 & & & & 101,65 & & & & 102,15 \\
\hline \multicolumn{3}{|c|}{ STDEV } & 4,61 & & & & 7,41 & & & & 4,15 \\
\hline
\end{tabular}




\section{KESIMPULAN}

Berdasarkan penelitian yang telah dilakukan serta hasil data yang diperoleh dapat dinyatakan bahwa metode analisis dalam penentuan benzena, toluena dan xilena pada sampel udara dan tanah menggunakan kromatografi gas, menunjukkan semua data yang diperoleh memenuhi syarat keberterimaan dengan parameter uji yang dilakukan, sehingga data dinyatakan valid dan dapat digunakan untuk analisa rutin.

\section{UCAPAN TERIMA KASIH}

Terima kasih kepada Pimpinan dan Staf Balai Keselamatan dan Kesehatan Kerja Samarinda, Kalimantan Timur untuk fasilitas laboratorium dan sampel yang disediakan dalam pelaksanaan penelitian ini.

\section{DAFTAR PUSTAKA}

Bahrami, A., Mahjub, H., Sadeghian, M., and Golbabaei, F., 2011. Determination of Benzene, Toluene, and Xylene (BTX) Concentrations in Air Using HPLC Developed Method Compared to Gas Chromatography. International Journal of Occupational Hygiene 3(1), 12-17.

Campos-Candel, A., Liobat-Estelles, M., and Mauri-Aucejo, A., 2009. Comparative Evaluation of Liquid Chromatography Versus Gas Chromatography Using a Betacyclodextrin Stationary Phase for the Determination of BTX in Occupational Environments. Talanta 78(4), 1286-1292.

González, A.G., and Herrador, M.A., 2007. A Practical Guide to Analytical Method Validation, Including Measurement Uncertainty and Accuracy Profiles. Trends in Analytical Chemistry 26, 227-238.

Harmita, 2004. Petunjuk Pelaksanaan Validasi Metode dan Cara Perhitungannya. Majalah Ilmu Kefarmasian 1(3), 117-135.

Indrawan, D., and Oginawati, K., 2014. Analisis Paparan BTX terhadap Pekerja di PT. Pertamina RU IV Cilacap. Jurnal Teknik Lingkungan 20(2), 132-141.

Krumholz, H.M., Chen J., Wang Y., Radford M.J., Chen Y.T., and Marciniak, T.A., 1999. Comparing AMI Mortality Among Hospitals in Patients 65 Years of Age and Older: Evaluating Methods of Risk Adjustment. Circulation 99(23), 2986-2992.

Miller, J.N., and Miller, J.C., 2005. Statistics and Chemometrics for Analytical Chemistry. $5^{\text {th }}$ Edition. Pearson Education Limited, England.

Moskovkina, M.N., and Milina, R.S., 2008. Environmental Organic Pollutants Analysis. Eurasian Journal of Analytical Chemistry 3(1), 123-133.

Panggabean, A.S., Amran, M.B., Buchari, and Achmad, S., 2009. Speciation of Organotin Compounds with Ion Pair-Reversed Phase Chromatography Technique. Eurasian Journal of Analytical Chemistry 4(2), 215-225. 
Panggabean, A.S., Pasaribu, S., Bohari, and Nurhasanah., 2014. Preconcentration of Chromium (VI) at Trace Levels Using Acid Alumina Resin with Column Method, Indonesian Journal of Chemistry 14(1), 51-56.

Panggabean, A.S, Pasaribu, S. P, and Kristiana, F., 2018. The Utilization of Nitrogen Gas a Carrier Gas in Determination of $\mathrm{Hg}$ Ions Using Cold Vapor-Atomic Absorption Spectrophotometer (CV-AAS). Indonesian Journal of Chemistry 18(2), 279-285.

Raeni, S.F., Haresmawati, U., Mulyasuryani, A., and Sabarudin, A., 2018. Evaluasi Pemisahan Alkilbenzena Menggunakan Kolom Monolith Berbasis Polimer Organik secara Kromatografi Cair Kinerja Tinggi. ALCHEMY Jurnal Penelitian Kimia 14(1), 37-50.

Riyanto, 2014. Validasi dan Verifikasi Metode Uji. Deepublish, Yogyakarta.

Safitri, H.I., Ryanitha, F.A., and Aryanti, F., 2013. Teknologi Ultrafiltrasi Untuk Pengolahan Air Terproduksi (Produced Water). Jurnal Teknologi Kimia dan Industri 2(4), 205-211.

Smith, M.T., 2010. Advances in Understanding Benzene Health Effects and Susceptibility. Annual Review of Public Health 31, 133-148.

Taufiq, M., Sabarudin. A., and Mulyasuryani, A., 2016. Pengembangan dan Validasi Metode Destruksi Gelombang Mikro untuk Penentuan Logam Berat Kadmium dan Timbal dalam Cokelat dengan Spektoskopi Serapan Atom (SSA). ALCHEMY 5(2), $31-37$.

White, A.J., Teitelbaum, S.L., Stellman, S.D., Beyea, J., Steck, S.E., Mordukhovich, I., McCarty, K.M., Ahn, J., Rossner, P., Santella, R.M., and Gammon, M.D., 2014. Indoor Air Pollution Exposure from Use of Indoor Stoves and Fireplaces in Association with Breast Cancer: a Case-Control Study. Environmental Health 13(108), 1-12.

Wispriyono, B., and Handoyo, E., 2016. Risiko Kesehatan Pajanan Benzena, Toluena, dan Xilena Petugas Pintu Tol. Jurnal Kesehatan Masyarakat 11(2), 188-194.

Yamada, E., Hosokawa, Y., Furuya, Y., Matsushita, K., and Fusu, Y., 2004. Simple Analysis of Volatile Organic Compounds (VOCs) in The Atmosphere Using Passive Samplers. Analytical Sciences 20, 107-112. 